\title{
Assessment of factors influencing the result of sputum cytology in bronchial carcinoma
}

\author{
M D CLEE AND D J M SINCLAIR \\ From the Department of Respiratory Medicine, Kings Cross Hospital, Dundee
}

ABSTRACT In a retrospective study of 377 patients with bronchial carcinoma, sputum had been reported positive or suspicious for malignant cells in $59.7 \%$. The most important factors contributing to a positive result were the histological cell type and the site of the tumour as assessed at bronchoscopy. Significantly more positive results were obtained in epidermoid tumours and those with a visible bronchoscopic abnormality. A higher proportion of positive results also occurred in large tumours, lower lobe tumours, and those associated with collapse and consolidation. The physical condition of the patient and the presence of infection in the sputum were not important factors contributing to a negative result. Although adequate numbers of sputum samples were collected the predominant problem was the large number of unsatisfactory sputum specimens. The preparation of the sputum specimens in the laboratory is important and is also a potential source of error.

Sputum cytology is an established technique in the investigation of suspected bronchial carcinoma. A number of reports have shown positive results in approximately $60 \%$ of cases of bronchial carcinoma where patients have submitted one or more satisfactory suptum specimens. ${ }^{12}$ This figure improves to $85 \%$ when four or more satisfactory specimens are examined. ${ }^{1}$ Previous publications have concentrated on the evaluation of this technique in terms of the success rate. There remains, however, a significent number of patients with bronchial carcinoma who have negative sputum cytology.

We report the results of our experience of sputum cytology over two and a half years and analyse the factors which may have contributed to the failure of cytological diagnosis.

\section{Methods}

The case notes and chest radiographs of patients with a final diagnosis of primary bronchial carcinoma during the period from October 1975 to April 1978 were reviewed. Patients were classified into two groups according to the result of sputum cytology. The positive group contained those patients with positive (class IV or class V) sputum

Address for reprint requests: Dr MD Clee, Department of Cardiology, Ninewells Hospital, Ninewells, Dundee DD1 9SY. cytology and suspicious (class III) cytology according to the criteria of Papanicolaou. ${ }^{3}$ The negative group was composed of those patients with no cytological evidence of carcinoma (class I and class II).

As $50 \%$ of patients with class III cells eventually prove to have bronchial carcinoma, ${ }^{4}$ and a suspicious report alerts the clinician to the possibility of this diagnosis, this category was included in the positive group.

The following data were obtained from the case records.

\section{SPUTUM RESULTS}

Specimens had been accepted as satisfactory for cytological assessment if alveolar macrophages were present; those containing upper respiratory tract secretions and saliva had been rejected as technically unsatisfactory. Two slides were examined from each specimen of sputum and graded according to the criteria of Papanicolaou. Sputum samples were also classified as mucoid or purulent on macroscopic appearance.

\section{OTHER INVESTIGATIONS}

The findings at bronchoscopy and the results of bronchial biopsy were noted. Histological findings from pleural biopsy, lymph node or other tissue biopsy, thoracotomy, and necropsy were recorded. 
The chest radiographs, postero-anterior, and lateral films, were reviewed with regard to tumour position and appearance, and the presence of any other associated abnormalities-that is, collapse or consolidation or both, and pleural fluid.

\section{CLINICAL ASSESSMENT}

Those patients with cerebral secondaries, metastatic disease contributing to poor expectoration, superior vena caval obstruction, or general debility were considered to be in poor physical condition. The remainder were accepted to be in good condition.

The results were analysed using a $\chi^{2}$ test.

\section{Results}

A final diagnosis of primary bronchial carcinoma had been made in 377 patients. The number of sputum samples submitted is shown in table 1 . Although $92.3 \%$ of the patients submitted three or more samples only $46.4 \%$ submitted three or more satisfactory samples. There were 225 patients $(59.7 \%)$ in the positive group-208 patients with positive cytology and 17 with suspicious cytology. Most of these patients $(90.2 \%)$ submitted an adequate number of samples; however only $53.8 \%$ submitted three or more satisfactory samples. In the negative group of 152 patients, $95.4 \%$ submitted at least three specimens indicating a reasonable attempt to obtain sputum for diagnostic purposes. Of the negative group $28.3 \%$ were unable to produce any satisfactory samples and only $35.5 \%$ submitted three or more satisfactory samples. The group of patients with negative cytology and three satisfactory samples were regarded as "true negatives" and were analysed further to determine the factors which contributed to a negative result.

The radiological position of the tumours in each group of patients is shown in table 2. There was no significant difference in tumour position between the groups. Sputum cytology was positive in $57 \%$ of the tumours situated in the upper lobes and $69 \%$ of the tumours in the lower lobes. A higher proportion of positive results has previously been reported in lower lobe tumours. ${ }^{4}$ Although not reaching statistical significance our results agree with this finding.

There was no significant difference in the radiological appearances of the tumours in each group of patients (table 3). Positive cytology was obtained in $55 \%$ of the tumours of less than $5 \mathrm{~cm}$ in diameter, in $62 \%$ of greater than $5 \mathrm{~cm}$ in diameter, and in $63 \%$ of the tumours associated with collapse and consolidation. This agrees with previous reports that larger tumours and those

Table 2 Radiological position of tumours in each group of patients $(\%)$

\begin{tabular}{lllll}
\hline & $\begin{array}{l}\text { All } \\
\text { patients } \\
(n=377)\end{array}$ & $\begin{array}{l}\text { Positive } \\
\text { group } \\
(n=225)\end{array}$ & $\begin{array}{l}\text { Negative } \\
\text { group } \\
(n=152)\end{array}$ & $\begin{array}{l}\text { True } \\
\text { negative } \\
\text { group } \\
(n=54)\end{array}$ \\
\hline Upper lobes & 60.2 & 58.2 & 63.2 & 66.7 \\
Lower lobes & 34.0 & 34.7 & 32.9 & 31.4 \\
Middle lobe & 5.8 & 7.1 & 3.9 & 1.9 \\
\hline
\end{tabular}

Table 3 Radiological appearance of tumours in each group of patients $(\%)$

\begin{tabular}{|c|c|c|c|c|}
\hline $\begin{array}{l}\text { Radiological } \\
\text { appearance }\end{array}$ & $\begin{array}{l}\text { All } \\
\text { patients } \\
(n=377)\end{array}$ & $\begin{array}{l}\text { Positive } \\
\text { group } \\
(n=225)\end{array}$ & $\begin{array}{l}\text { Negative } \\
\text { group } \\
(n=152)\end{array}$ & $\begin{array}{l}\text { True } \\
\text { negative } \\
\text { group } \\
(n=54)\end{array}$ \\
\hline \multicolumn{5}{|l|}{ Tumour mass } \\
\hline $\begin{array}{l}\text { Rounded less than } \\
2 \mathrm{~cm}\end{array}$ & $4 \cdot 8$ & $4 \cdot 0$ & $5 \cdot 9$ & $3 \cdot 7$ \\
\hline Rounded 2-4.9 cm & $38 \cdot 5$ & $36 \cdot 0$ & $42 \cdot 2$ & 38.9 \\
\hline $\begin{array}{l}\text { Rounded greater } \\
\text { than } 5 \mathrm{~cm}\end{array}$ & $26 \cdot 5$ & $27 \cdot 6$ & 25.0 & $24 \cdot 1$ \\
\hline $\begin{array}{l}\text { Collapse and/or } \\
\text { consolidation, } \\
\text { pleural fluid }\end{array}$ & $28 \cdot 6$ & $30 \cdot 2$ & $26 \cdot 3$ & $33 \cdot 3$ \\
\hline $\begin{array}{l}\text { Root/mediastinal } \\
\text { shadows only }\end{array}$ & $1 \cdot 6$ & $2 \cdot 2$ & 0.6 & - \\
\hline
\end{tabular}

Table 1 Number of sputum samples (\%) and number of satisfactory samples (\%) submitted by each. group of patients ( $n=$ number of patients)

\begin{tabular}{|c|c|c|c|c|c|c|}
\hline \multirow[t]{2}{*}{ Number of sputum samples } & \multicolumn{2}{|l|}{$\begin{array}{l}\text { All patients } \\
(n=377)\end{array}$} & \multicolumn{2}{|l|}{$\begin{array}{l}\text { Positive group } \\
(n=225)\end{array}$} & \multicolumn{2}{|l|}{$\begin{array}{l}\text { Negative group } \\
(n=152)\end{array}$} \\
\hline & $\begin{array}{l}\% \text { submitting } \\
\text { sputum }\end{array}$ & $\begin{array}{l}\% \text { submitting } \\
\text { satisfactory sputum }\end{array}$ & $\begin{array}{l}\% \text { submitting } \\
\text { sputum }\end{array}$ & $\begin{array}{l}\% \text { submitting } \\
\text { satisfactory sputum }\end{array}$ & $\begin{array}{l}\% \text { submitting } \\
\text { sputum }\end{array}$ & $\begin{array}{l}\% \text { submitting } \\
\text { satisfactory } \\
\text { sputum }\end{array}$ \\
\hline One or more & 100 & $88 \cdot 5$ & 100 & 100 & 100 & $\mathbf{7 1 \cdot 7}$ \\
\hline Two or more & 99.5 & $71 \cdot 0$ & $99 \cdot 5$ & $81 \cdot 3$ & $99 \cdot 3$ & 55.9 \\
\hline Three or more & $92 \cdot 3$ & $46 \cdot 4$ & $90 \cdot 2$ & $53 \cdot 8$ & $95 \cdot 4$ & $35 \cdot 5$ \\
\hline Four or more & $38 \cdot 7$ & $19 \cdot 0$ & $41 \cdot 7$ & $21 \cdot 3$ & $34 \cdot 2$ & $15 \cdot 7$ \\
\hline
\end{tabular}


associated with collapse and consolidation are more likely to yield a positive result. ${ }^{4}$

Histological confirmation of the tumour cell type by means other than cytology was obtained in 73 of the positive group, 74 of the negative group, and 31 of the true negative group. The findings were classified according to the World Health Organisation criteria ${ }^{5}$ and are shown in table 4 . In the negative and true negative groups there was a significantly smaller number of patients with epidermoid cell tumours $(p<0.05)$. Malignant epidermoid cells are readily identified in sputum samples and tumours of this cell type yield a higher proportion of positive results. ${ }^{1}$ Thus the histological cell type is important in determining the outcome of sputum cytology.

Table 4 Histological cell type of tumours in each group of patients $(\%)$

\begin{tabular}{lllll}
\hline $\begin{array}{l}\text { Histological } \\
\text { cell type }\end{array}$ & $\begin{array}{l}\text { All } \\
\text { patients } \\
(n=147)\end{array}$ & $\begin{array}{l}\text { Positive } \\
\text { group } \\
(n=73)\end{array}$ & $\begin{array}{l}\text { Negative } \\
\text { group } \\
(n=74)\end{array}$ & $\begin{array}{l}\text { True } \\
\text { negative } \\
\text { group } \\
(n=31)\end{array}$ \\
\hline Epidermoid & $48 \cdot 3$ & $57 \cdot 5$ & $39 \cdot 2^{*}$ & $35 \cdot 5^{*}$ \\
Small cell anaplastic & $14 \cdot 3$ & $11 \cdot 0$ & $17 \cdot 6$ & $16 \cdot 1$ \\
Adenocarcinoma & $8 \cdot 8$ & $11 \cdot 0$ & $6 \cdot 7$ & $3 \cdot 2$ \\
Large cell anaplastic & $28 \cdot 6$ & $20 \cdot 5$ & $36 \cdot 5$ & $45 \cdot 2^{*}$ \\
\hline
\end{tabular}

$* p<0.05$ when compared with the positive group.

One hundred and fifty-three patients in the positive group were examined bronchoscopically and $127(83 \%)$ of these had a visible abnormality and were, therefore, classified as having central tumours. The remaining $26(17 \%)$ had no visible abnormality and the tumours were regarded as peripheral in site. In the negative group 112 patients had bronchoscopy, $80(71.4 \%)$ had central, and $32(28.6 \%)$ peripheral tumours. In the true negative group 22 patients $(50 \%)$ had a central lesion and 22 a peripheral lesion. This difference in tumour site betwen the positive group and true negative group was highly significant $(p<0.001)$. Central tumours yield a higher proportion of positive results; ${ }^{4}$ thus the relatively smaller proportion of patients with central tumours in the negative and especially the true negative groups makes positive cytology less likely.

Sputum samples were purulent in $37.3 \%$ of the patients in the positive group, $36.8 \%$ in the negative group, and $35.2 \%$ in the true negative group. There was no significant difference between the groups.

In the positive group $46.7 \%$ of the patients were considered to be in poor physical condition, in the negative group $54.6 \%$, and in the true negative group $48 \cdot 1 \%$. While slightly more of the patients in the negative group were in poor physical condition, this was not statistically significant and is not an important factor in determining the outcome of cytology.

\section{Discussion}

Sputum cytology yielded evidence of malignancy in $59.7 \%$ of our patients. Positive cytology was more likely where tumours were large, situated in the lower lobes, or associated with collapse or consolidation or both. The two most important factors were epidermoid histology and the tumour site as assessed at bronchoscopy (table 5).

Table 5 Site of tumour at bronchoscopy (central or peripheral) in those patients with histological confirmation of cell type (epidermoid or nonepidermoid)

\begin{tabular}{|c|c|c|c|c|}
\hline & \multicolumn{2}{|l|}{ Central } & \multicolumn{2}{|l|}{ Peripheral } \\
\hline & $\begin{array}{l}\text { Number } \\
\text { of patients }\end{array}$ & $\begin{array}{l}\text { Percentage } \\
\text { of patients } \\
\text { in the } \\
\text { positive } \\
\text { group }\end{array}$ & $\begin{array}{l}\text { Number } \\
\text { of patients }\end{array}$ & $\begin{array}{l}\text { Percentage } \\
\text { of patients } \\
\text { in the } \\
\text { positive } \\
\text { group }\end{array}$ \\
\hline $\begin{array}{l}\text { Epidermoid } \\
\text { Non-epidermoid }\end{array}$ & $\begin{array}{l}46 \\
40\end{array}$ & $\begin{array}{l}71 \cdot 7 \\
52 \cdot 5\end{array}$ & $\begin{array}{l}13 \\
15\end{array}$ & $\begin{array}{l}38 \cdot 5 \\
20 \cdot 0\end{array}$ \\
\hline
\end{tabular}

There were significantly more patients in the epidermoid group with positive cytology $(\mathrm{p}<0.05)$.

There were significantly more patients in the central group with positive cytology $(p<0 \cdot 01)$.

In $40.3 \%$ of our patients the diagnosis was not confirmed by sputum cytology. Many factors may contribute to this: (1) inadequate number and unsatisfactory sputum specimens; (2) sputum infected and frankly purulent; (3) patient unable to produce sputum; (4) size and position of the tumour; (5) histology of the tumour; (6) tumour does not exfoliate; (7) degeneration of malignant cells in the sputum before examination.

In this series a significant number of patients in the negative group (28.3\%) produced no satisfactory specimens. For consistent and reliable results special care must be taken to ensure adequate and satisfactory sputum samples. The staff collecting the samples should be experienced in the correct technique and should give explicit instructions to the patient. Written instructions have been shown to be of benefit. ${ }^{4}$ There is good evidence that the greater the number of satisfactory samples examined the greater the likelihood of confirming the diagnosis. ${ }^{126}$ As an experienced cytologist requires 10-20 minutes to examine each slide, ${ }^{7}$ for practical purposes it is 
generally accepted that three or four satisfactory samples are optimal.

The presence of pus in the specimens makes cytological examination unsatisfactory and contributes to a negative result. ${ }^{6}$ This was not an important factor as in the majority of patients the sputum was mucoid and purulence was present in a similar proportion of the positive and negative groups. A large number of patients submit secretions from the upper respiratory tract or saliva. All samples should, therefore, be screened for the presence of alveolar histiocytes before proceeding with the examination for malignant cells.

Many patients with advanced bronchial carcinoma are in poor physical condition and might be unable to co-operate sufficiently to produce satisfactory samples. Although there was a larger number of patients in poor condition in the nega. tive group this was not statistically significant and thus was not a major factor contributing to negative cytology. It is in these patients that sputum cytology is particularly useful as it may obviate more invasive investigations.

Degeneration of tumour cells, can occur if there is a long delay in reaching the laboratory. ${ }^{\circ}$ In scanty specimens drying can also cause damage to the cells, resulting in failure of cytological diagnosis. Better results are obtained if the slides are smeared and fixed immediately, and prepared by an experienced cytologist or technician. ${ }^{4}$ However this is not practical in the ward itself. The handling and preparation of the sputum samples in the laboratory is an important factor determining the outcome of cytology. For optimal results suspicious portions of sputum or blood tinged areas should be carefully selected and then gently crushed between two slides to form a uniform smear. ${ }^{8}$ Extremely thin or thick smears are microscopically unsatisfactory. Alternatively the sputum samples may be homogenised before spreading on the slides. ${ }^{8}$ These techniques are time consuming and require considerable attention to detail which can easily be neglected in a busy routine laboratory.
In conclusion there was no single reason why $40.3 \%$ of patients with bronchial carcinoma had persistently negative sputum cytology. Many factors interact and were of varying importance in each individual case. The predominant practical problem for the clinician, however, remains the large number of patients who submit unsatisfactory sputum specimens, and with more care and attention during the collection of specimens and proper education of staff and patients this $\underset{\times}{\vec{x}}$ should be remediable.

We thank Dr RN Johnston, Dr RA Clark, and Dr DH Smith for permission to examine the records of patients under their care, Dr HLD 윽 Duguid for helpful advice, the staff of the $\rightarrow$ Cytology Laboratory, and $\mathrm{Mr} \mathrm{S}$ Ogston for $\mathbb{T}$ statistical analysis.

\section{References}

1 Oswald NC, Hinson KFW, Canti G, Miller AB. The diagnosis of primary lung cancer with special reference to sputum cytology. Thorax 1971; 26: $\stackrel{\circ}{ه}$ 623-31.

2 Hinson KFW, Kuper SWA. The diagnosis of lung $\overrightarrow{\bar{\sigma}}$ cancer by examination of sputum. Thorax, 1963; 18:350-3.

3 Papanicolaou GN. New procedure for staining vaginal smears. Science 1942; 95:438-9.

4 Duguid, HLD, Huish, DW. Clinical evaluation of cytodiagnosis in bronchial carcinoma. Br Med $\underset{\times}{\stackrel{2}{2}}$ $J$ 1963; 2:287-91.

5 Kreyburg L, Liebow AA, Uehlinger EA. Histological typing of lung tumours. Geneva: World Health Organisation, 1967.

6 Philps FR. The identification of carcinoma cells 0 in sputum. Br J Cancer 1954; 8:67-96.

7 Oswald NC, Hinson KFW, Canti G et al. Survey of the sputum cytology service in England and Wales. Thorax 1975; 30:489-96.

8 Wied GL, Koss LG, Reagan JW. Compendium on diagnostic cytology (fourth edition). Tutorial of Cytology 1976; 4:275-88. 